\title{
PROFIL HASIL PEMERIKSAAN MINI MENTAL STATEEXAMINATION (MMSE) PADA WANITA POSTMENOPAUSE DI POSYANDU LANSIA REJOAGUNG, WILAYAH KERJA PUSKESMAS KEDUNGWARU, TULUNGAGUNG, JAWA TIMUR
}

\author{
Muhamad Wildan, ${ }^{1}$ M. Ma'roef ${ }^{2}$, Tonthowi Djauhari ${ }^{3}$
}

Fakultas Kedokteran Univesitas Muhammadiyah Malang, J1. Bendungan Sutami No. 188, Malang, 65114, Indonesia, +62341582060

\begin{abstract}
ABSTRAK
Profil Hasil Pemeriksaan Mini Mental State Examination (MMSE) pada Wanita Postmenopause di Posyandu Lansia Rejoagung, Wilayah kerja puskesmas Kedungwaru, Tulungagung, Jawa timur. Wanita pada masa postmenopause akan mengalami penurunan produksi hormon estrogen. Beberapa penelitian menunjukkan bahwa menurunnya hormon estrogen dapat menyebabkan terjadinya aterosklerosis yang merupakan salah satu faktor penyebab gangguan kognitif. Penelitian ini bertujuan mengetahui profil hasil pemeriksaan MMSE pada wanita postmenopause. Penelitian ini merupakan studi deskriptif observasional dengan pengambilan sampel secara total sampling terhadap semua wanita di posyandu lansia Rejoagung yang sudah postmenopause. Instrumen yang digunakan ialah Mini Mental State Examination. Hasil pemeriksaan MMSE wanita postmenopause didapatkan insiden gangguan kognitif terbanyak pada usia 65-69 tahun, dengan 31,2\% stadium ringan dan 56,3\% stadium sedang. Insiden gangguan kognitif terbanyak terjadi pada wanita postmenopause dengan pendidikan terakhir SMP dengan 54\% stadium ringan. Didapatkan juga gangguan kognitif terbanyak pada wanita dengan lama masa postmenopause 11-15 tahun sekitar 45\% gangguan kognitif stadium ringan dan wanita dengan lama masa postmenopause $>15$ tahun sekitar 33,3\% stadium sedang. Berdasarkan hasil pemeriksaan MMSE pada wanita postmenopause didapatkan sebanyak 45\% dari sampel yang mengalami gangguan kognitif dan 55\% yang tidak mengalami gangguan kognitif.
\end{abstract}

Kata kunci: Wanita postmenopause, gangguan kognitif, MMSE

\section{ABSTRACT}

The Profile of Mini Mental State Examination (MMSE) Result of The Post menopause Women at Posyandu Lansia Rejoagung, Kedungwaru Public Health Center Working Area, East Java. Women in the post menopause period will suffer the decreasing of estrogen hormone production. Several studies have proven that less estrogen hormone can lead atherosclerosis, this condition is one of the causes of cognitive impairment. Objective: To know the profile of Mini Mental State Examination (MMSE) result of the post menopause women. This study was an observational descriptive with total sampling method of the women at Posyandu Lansia Rejoagung that had reached post menopause period. The instrument that used in this study was Mini Mental State Examination. The result on the post menopause women found that the highest incidence of cognitive impairment occurs at 65-69 years old, 31,2\% were mild criteria and 56,3\% were moderate criteria. The highest incidence of cognitive impairment occurs on junior high school education level with $54 \%$ were mild criteria. Based on the result also found 45\% women with 11-15 years post menopause period suffer mild cognitive impairment and 33,3\% women with more than 15 years post menopause period suffer moderate cognitive impairment. Based on the result of MMSE on the post menopause women found that 45\% samples suffered cognitive impairment and 55\% didn't suffer cognitive impairment.

Key word: Post menopause women, cognitive impairment, MMSE.

\section{PENDAHULUAN}

Kognitif adalah kemampuan berpikir dan memberikan rasional, termasukproses mengingat, menilai, orientasi, persepsi dan memperhatikan (Stuart \& Sundeen, 1987). Kognitif merupakan semua proses dan produk fikiran untukmencapai pengetahuan yang berupa aktifitas mental, seperti mengingat, mengkategorikan, dan memecahkan masalah (Nevid, 2003).Prevalensi gangguan kognitif berupa mudah lupa (forgetfulness) dilaporkan sekitar 44\% pada masa transisi menopause awal, 44,8\% pada masa transisi akhir menopause dan $42 \%$ pada masa postmenopause (Woods, 2007). Suatu survei yang dilakukan oleh Perkumpulan Menopause Indonesia (PERMI) di 5 kota di Indonesia (Jakarta, Semarang, Bandung, Yogyakarta dan Malang) menunjukkan keluhan sering lupa yang tinggi $(59,9 \%)$ pada wanita menopause (PERMI, 2007). Menopause adalah berhentinyasiklus haid terutama karena ketidakmampuan sistem neurohormonal Untuk 
mempertahankan stimulasiperiodiknya pada sistem endokrin (Potter \& Perry, 2005). Baziad menyebutkanbahwa menopause sebagai perdarahan rahim terakhir yang masih diatur oleh hormonovarium. Istilah menopause digunakan untuk menyatakan suatu perubahan hidupdan pada saat itulah seorang wanita mengalami periode terakhir masa haid (Kasdu, 2004).Menopause rata-rata terjadi pada usia 50 tahun. Tetapi bisa terjadi secara normal pada wanita yang berusia 40 tahun. Biasanya ketika mendekati masa menopause, lama dan banyaknya darah yang keluar pada siklus menstruasicenderung bervariasi, tidak seperti biasanya. Pada beberapa wanita, aktivitasmenstruasi berhenti secara tiba-tiba, tetapi biasanya berhenti secara bertahap (baikjumlah maupun lamanya) dan jarak antara 2 siklus menjadi lebih dekat atau lebih jarang. Ketidakteraturan ini terjadi selama 2-3 tahun sebelum akhirnya siklus berrhenti (Irawati, 2002).Purwantyastuti (2005) mengatakan bahwa umumnyA wanita Indonesia mengalami menopause di usia 45-55 tahun. Hal yang sama juga dikatakan Braam(1981), yang menyatakan bahwa sebagaian besar wanita, menopause terjadi padaumur antara 45-55 tahun. Meskipun begitu ada beberapa wanita yang mengalamimentruasi terakhir sebelum umur 45 tahun, tetapi ada pula wanita yang sudah berumur 57 tahun baru mendapatkan menstruasi terakhir (Purwanto, 2007).Menopause terjadi pada akhir suatu siklus yang dimulai pada masa remajadengan munculnya menarche. Secara umum, wanita barat pertama kali mendapatmenstruasi pada usia 12 tahun, sedangkan haid berakhir pada usia 45 sampai 53 tahun. Relatif sedikit wanita mulai menopause pada usia 40 tahun dan beberapamengalaminya setelah berusia 53 tahun (Reitz, 1993). Hal ini disimpulkan bahwa usia

seorang wanita akanmengalamimenopause sangat bervariatif. Hal ini sangat bergantung pada berbagai faktoryang mempengaruhinya. Umumnya dapat diambil rata-ratanya seorang wanitaakan mengalami menopause sekitar pada usia 45 sampai 50 tahun (Kasdu, 2004).

Gangguan kognitif pada wanita menopause diduga disebabkan oleh kekurangan hormon estrogen. Beberapa penelitian menunjukkan bahwa estrogen bersifat sebagai neuroprotektor, sehingga dengan menurunnya kadar estrogen dapat menyebabkan gangguan kognitif (Chen $\mathrm{SH}$, 2006). Hormon estrogen bersifat sebagai neuroprotektor dengan mencegah terjadinya penyumbatan pembuluh darah yang berbahaya (aterosklerosis). Aterosklerosis dapat menyebabkan terjadinya kelainan vaskuler, gangguan pembuluh darah serebral dan lesi parenkim pada otak, yaitu jika pada area ventral hipokampus terjadi gangguan, sehingga menyebabkan gangguan kognitif pada wanita menopause (Cutter WJ, 2003).

Melalui penelitian dengan binatang percobaan diketahui bahwa estrogen mempunyai beberapa peran di otak, dan hal ini sudah dilakukan lebih dari 40tahun yang lalu. Studi pertama yang dilakukan pada binatang, terfokus pada aksi estrogen di hipotalamus yang mempengaruhi proses ovulasi dan prilaku reproduktif. Selain berperan pada fungsi reproduktif, estrogen juga berperan dalam fugsi nonreproduksi antara lain fungsi kognitif dan memori, status afektif dan mood, koordinasi motor, eksitabilitas sinap, dan regulasi nyeri. Disamping itu estrogen juga mempengaruhi sistemserotonergik, non adrenergik, dopaminergik dan kolinergik di otak, dimana semua sistem tersebut berperan penting pada fungsi kognitif, memori serta status afektif dan mood. Estrogenbekerja pada beberapa sistem dan daerah di otak, antara lain pada sistem kolinergik dibasal forebrain, sistem serotonergik midbrain, sisem dopaminergik midbrain dan hipotalamus, sistem katekolaminergik brainstem, hippokampus, spinal cord, dan pada sel glia (McEwen, 1999). Estrogen bekerja di hippokampus secara langsung maupun tidak langsung. Estrogen bekerja secara langsung di hippokampus telah dibuktikanmelalui studi invitro (Murphy \& Segal, 1996 dalam Tri Lam \& Larenth, 2003).Estrogen bekerja di hippokampus secara tidak langsung melalui area subcortikal yang sensitif terhadap estrogen, yaitu area supra mamilaria, Medial Septum-Diagonal Band of Broca (MSDB) dan raphe median (Larenth et al, 2001 Tri Lam \& Larenth, 2003). Peneltian tentang efek estrogen pada tikus telah menunjukkan bahwaestrogen meningkatkan memori (Luine et al, 2003). Estrogen meningkatkan densitas dan jumlah spine dendrit dan sinap di hippokampus CA1 (Murphy, 1998)serta meningkatkan eksitabilitas sel piramidal (Nicolletti, 1985). Mekanismeutama yang mungkin menyebabkan hal tersebut adalah estrogen meningkatkan ikatan NMDA dan AMPA (Good, 1999). Sistem neurotransmitter yang dominan mengatur fungsi memori adalah sistem kolinergik. Telah dibuktikan bahwa efekestrogen dalam meningkatkan ikatan reseptor NMDA di CA1 diperantarai oleh sistem kolinergik dangan asetilkolin sebagai neurotransmitternya (Daniel \& Dohanich, 2001).

Gangguan kognitif yang berat pada wanita menopuase dapat menyebabkan disfungsi pada kehidupan seharihari, sehingga tingkat ketergantungan wanita menopause terhadap orang disekitarnya menjadi tinggi (Rochmah et al, 2006). Penurunan fungsi kognitif pada wanita menopause dapat dideteksi denganmelakukan pemeriksaan Mini mental State Examination (MMSE), yaitu suatu instrumen untuk menilai fungsi kognitif yang mencakup domain orientasi,registrasi, atensi, kalkulasi, recall, dan fungsi bahasa. MMSE dapat menjadi pemeriksaan penapisan, untuk pedoman evaluasi lebih lanjut adanya disfungsi kognitif sehingga dapat menginformasikan pada penderita, keluarga dan pengasuhnya mengenai gambaran penurunan fungsi kognitif yang terjadi, MMSE juga dapat menjadi data dasar untuk melihat efektifitas dari pengobatan dan menentukan progresifitas dari gangguan kognitif (Folstein et al, 1993). Beberapa penulis melaporkan bahwa nilai MMSE dipengaruhi oleh beberapa faktor seperti faktor sosiodemografik, termasuk didalamnya adalah umur, jenis kelamin, tingkat pendidikan, pekerjaan dan status perkawinan, yangkedua adalah faktor lingkungan dan faktor behavior, yang termasuk pada faktor ini adalah beban kehidupan secara umum, stress fisik, kontak sosial, aktifitasfisik, merokok dan minum alkohol. Penelitian lain melaporkan bahwa umur dan pendidikan akan mempengaruhi nilai MMSE. Sedangkan 
peneliti lain melaporkan bahwa yang mempengaruhi nilai MMSE hanya tingkat pendidikan saja (Folstein, 1993).

Pemeriksaan MMSE mudah dilakukan yaitu dengan memberi nilai untuk beberapa fungsi kognitif. Tes ini menilai orientasi waktu, tempat, ingatan halsegera, memori jangka pendek dan kemampuan pengurangan serial atau membaca terbalik, selain itu juga mengukur kemampuan konstruksional dan pemakaian bahasa. Tes ini dapat dilakukan oleh dokter, perawat atau orang awan dengan sedikit pelatihan dan hanya membutuhkan waktu sekitar 10 menit (Folstein, 1993). Beberapa modifikasi dari MMSE telah dilakukan supaya dapat digunakan pada negara tertentu. Poungvarrin melakukan modifikasi MMSE sesuai dengan pendidikan dan sosial tradisi masyarakat Thailand menjadi Thai Mental State Examination (TSME) dan jumlah nilai TSME sama dengan MMSE (Folstein, 1993). Terdapat b e be ra pa perbedaan diantara para ahli dalam menentukan klasifikasi penilaian MMSE. Grut et al dan Folstein et al mendapatkan nilainormal MMSE adalah lebih besar atau sama dengan 27, sedangkan Wind mendapatkan nilai MMSE normal (27 - 30) curiga gangguan fungsi kognitif (22-26), pasti gangguan fungsi kognitif $(<21)$. Sedangkan Kukull et al menyatakanbahwa nilai MMSE normal adalah lebih besar atau sama dengan 27 (Folstein, 1993). Menurut Wibisono (2003) yaitu nilai 2730 (normal), nilai 21-26 (stadiumringan), nilai 10-20 (stadium sedang), nilai $<10$ (stadium lanjut).Menurut National Institute of Mental Health USA, pemeriksaan MMSE memiliki sensitivitas $87 \%$ dan spesifitasnya $82 \%$ untuk mendeteksi demensia danpenurunan fungsi kognitif (Tatemichi et al, 1997).

Kabupaten Tulungagung sendiri merupakan salah satu Kabupaten di Jawa'Timur yang berstruktur tua dengan jumlah penduduk 970.429 jiwa, dengan uraian278.513 jiwa berusia 45-59 tahun dan 173.811 jiwa lebih dari 60 tahun (BPPD Kabupaten Tulungagung, 2005). Kepadatan penduduk terkonsentrasi di 3 kecamatan yaitu: Kecamatan Tulungagung, Kecamatan Kedungwaru, Kecamatan boyolangu. Berdasarkan hasil survei Kecamatan Kedungwaru merupakan kecamatan dengan program posyandu lansia yang paling aktif. Penyakit yang diderita oleh lansia pada umumnya adalahpenyakit kronik yang sudah berlangsung lama dan menahun. Beberapa daripenyakit kronik yang kerap diderita merupakan salah satu faktor resiko terjadinyagangguan kognitif (Kaplan et al, 2010).Penelitian ini dilakukan untuk mengetahui profil hasil pemeriksaan Mini Mental State Examination (MMSE) pada wanita postmenopause di posyandu lansia Rejoagung wilayah kerja puskesmas Kedungwaru Tulungagung Jawa Timur.

\section{METODE PENELITIAN}

Jenis penelitian yang digunakan pada penelitian ini adalah deskriptif observasional dengan pendekatan studi kasus. Penelitian dilakukan di posyandu lansia Rejoagung wilayah kerja Puskesmas Kedungwaru, Tulungagung, Jawa Timur. Penelitian inidilakukan pada bulan Agustus 2011. Populasi penelitian ini adalah semua wanita di posyandu lansia Rejoagung wilayah kerja Puskesmas
Kedungwaru, Tulungagung, Jawa Timur sejumlah 75 orang. Sedangkan sampelnya wanita yang sudah mengalami masa postmenopause di posyandu lansia Rejoagung, wilayah kerja Puskesmas Kedungwaru, Tulungagung, Jawa Timur yang memenuhi kriteria inklusidan tidak termasuk kriteria eksklusi, dihitung dengan formula Slovin, maka didapatkan sebanyak 63 sampel. Pengambilan Sampel dengan teknik Total sampling metode non-random sampling. Data penelitian diperoleh dari data primer dan sekunder pada wanita usia postmeopause, yang dari hasil wawancara langsung terhadapwanita didapatkan keluhan tersebut.

\section{HASIL DAN PEMBAHASAN}

Pada penelitian ini Berdasarkan hasil data primer jumlah wanita di posyandu lansia Rejoagung yang sudah mengalami postmenopause dan yang memenuhi kriteria inklusi, sampel penelitian dapat diklasifikasikan dalam beberapa tabel berikut

\section{Tabel 1. Distribusi wanita postmenopause} berdasarkan usia

\begin{tabular}{ccc}
\hline Usia & Frekuensi & Presentase (\%) \\
$55-59$ & 19 & 30 \\
$60-64$ & 29 & 45 \\
$65-69$ & 16 & 25 \\
\hline Jumlah & 64 & 100 \\
\hline
\end{tabular}

Tabel 1 menunjukkan distribusi wanita postmenopause berdasarkan usia, pada penelitian ini didapatkan jumlah wanita terbanyak yang datang ke posyandu lansia Rejoagung adalah usia 60-64 tahun dengan persentase 45\%.Hal inisesuaidenganpenelitian (Wahono, 2010) di Solo yang menyebutkan pemanfaatan posyandu lansia adalah rata-rata berumur 60 tahunkeatas, danHardywinoto (2005) juga menyatakan bahwa pada umur tersebut sangat butuh sarana pelayanan kesehatan terkait penurunan berbagai fungsi atau kelemahan, dan rentannya terhadap berbagai penyakit, karena berkurangny adaya tahan tubuh ketika berusia lanjut.

\section{Tabel 2. Distribusi sampel berdasarkan pendidikan terakhir}

\begin{tabular}{ccc}
\hline $\begin{array}{c}\text { Pendidian } \\
\text { Terakhir }\end{array}$ & Frekuensi & Presentase (\%) \\
SD & 26 & 41 \\
SMP & 13 & 20 \\
SMA & 20 & 31 \\
D3 & 3 & 5 \\
S1 & 2 & 3 \\
Jumlah & 64 & 100 \\
\hline
\end{tabular}

Tabel 2 menunjukkan distribusi mengenai wanita postmenopause yang datang ke posyandu lansia Rejoagung dengan pendidikan terakhir terbanyak adalah pendidikan SD, yaitu dengan persentase $41 \%$. Hal ini dikarenakan mayoritas masyarakat sekitar yang datang ke posyandu termasuk golongan sosial ekonomi yang rendah maka kesadaran untuk mengenyam kursi pendidikan kurang sehingga akan berpengaruh terhadap pola hidup, seperti kebiasaan hidup sehat, yang menyebabkan banyak wanita 
yang sudah memasuki usia lanjut datang ke posyandu untuk memeriksakan kesehatannya.Sejalan dengan Purwanto (2000), yang mengemukakan bahwa salah satu faktor yang berpengaruhi pada perilaku kesehatan adalah tingkat pendidikan seseorang.

Tabel 3. Distribusi wanita menopause berdasarkan lama masa postmenopause

\begin{tabular}{ccc}
\hline Lama & Frekuensi & $\begin{array}{c}\text { Presentase } \\
(\%)\end{array}$ \\
postmenopause & & 37 \\
1-5 tahun & 24 & 44 \\
6-10 tahun & 28 & 14 \\
11-15 tahun & 9 & 5 \\
>15 tahun & 3 & 100 \\
\hline Jumlah & 64 & \\
\hline
\end{tabular}

Tabel 3 menunjukkan distribusi wanita dengan lama masa postmenopause 6-10 tahun yang datang ke posyandu lansia Rejoagung merupakan yang terbanyak (44\%), hal ini disebabkan karena sebagian besar wanita yang datang yaitu wanita yang sudah berusia 60-64 tahun, sehingga menyebabkan rentang lama masa postmenopause yang terbanyak adalah 6 sampai 10 tahun.Menurut Baziad (2003), bahwa postmenopause terjadi bila telah mengalami menopause 12 bulan sampai menuju ke senium. Senium adalah postmenopause lanjut, yaitu setelah berusia 65 tahun. Batasan usia postmenopause terjadi pada usia 55 sampai 65 tahun. Pada fase Postmenopause dimana ovarium sudah tidak berfungsi sama sekali, kadar estradiol berada antar 20$30 \mathrm{pg} / \mathrm{mI}$ dan kadar hormon gonadtropin biasanya meningkat. Peningkatan hormon gonadtropin ini disebabkan oleh terhentinya produksi inhibin akibat tidak tersedianya folikel dalam jumlah yang cukup. Akibat rendahnya kadar estradiol, endometrium menjadi atopik dan tidak mungkin muncul haid lagi sehingga terjadi fase postmenopause pada wanita.

\section{Tabel 4. Hasil pemeriksaan MMSE pada wanita postmenopause berdasarkan usia}

\begin{tabular}{|c|c|c|c|c|c|}
\hline \multirow[t]{2}{*}{ Usia } & \multicolumn{4}{|c|}{ Tingkat gangguan kognitif(MMSE) } & \multirow{2}{*}{$\begin{array}{c}\text { Presentas } \\
\text { e (\%) }\end{array}$} \\
\hline & $\begin{array}{c}\text { Normal } \\
27-30\end{array}$ & $\begin{array}{l}\text { Ringan } \\
(21-26)\end{array}$ & $\begin{array}{l}\text { Sedang } \\
(10-20)\end{array}$ & $\begin{array}{l}\text { Lanjut } \\
(<10)\end{array}$ & \\
\hline $55-59$ & $\begin{array}{c}15 \\
(79 \%)\end{array}$ & $\begin{array}{c}4 \\
(21 \%)\end{array}$ & 0 & 0 & 100 \\
\hline $60-64$ & $\begin{array}{c}18 \\
(62 \%)\end{array}$ & $\begin{array}{c}8 \\
(27 \%)\end{array}$ & $\begin{array}{c}3 \\
(11 \%)\end{array}$ & 0 & 100 \\
\hline $65-69$ & $\begin{array}{c}2 \\
(12,5 \%) \\
\end{array}$ & $\begin{array}{c}5 \\
(31,2 \%) \\
\end{array}$ & $\begin{array}{c}9 \\
(56,3 \%) \\
\end{array}$ & 0 & 100 \\
\hline Jumlah & $\begin{array}{c}35 \\
(54,7 \%)\end{array}$ & $\begin{array}{c}17 \\
(26,6 \%)\end{array}$ & $\begin{array}{c}12 \\
(18,7 \%)\end{array}$ & 0 & $\begin{array}{c}64 \\
(100 \%)\end{array}$ \\
\hline
\end{tabular}

Tabel 4 menunjukkan data mengenai hasil pemeriksaan MMSE pada wanita postmenopause berdasarkan usia, dari penelitian ini didapatkan usia 65-69 tahun dengan persentase yang tinggi pada gangguan kognitif stadium ringan $(31,2 \%)$ dan stadium sedang $(56,3 \%)$. Hasil data penelitian ini menunjukkan bahwa usia merupakan salah satu faktor yang mempengaruhi terjadinya penurunan fungsi kognitif, hal ini sesuai dengan teori Folstein, (1993) yang menyatakan salah satu faktor yang mempengaruhi hasil pemeriksaan MMSE adalah usia dan tingkat pendidikan seseorang. Teori lainnya yang menyatakan semakin meningkatnya usia seseorang maka akan semakin tinggi pula tingkat keterbatasan dalam proses berfikir dan aktifitas, yaitu dikarenakan akibat hilangnya mekanisme autoregulasi otak sehingga banyak lansia menjadi rentan terhadap terjadinya gangguan kognitif. (Arisman, 2004).

\begin{tabular}{|c|c|c|c|c|c|}
\hline \multirow{2}{*}{$\begin{array}{c}\text { Pendi } \\
\text { dikan } \\
\text { Terak } \\
\text { hir }\end{array}$} & \multicolumn{4}{|c|}{ Tingkat gangguan kognitif (MMSE) } & \multirow{2}{*}{$\begin{array}{l}\text { Present } \\
\text { ase (\%) }\end{array}$} \\
\hline & $\begin{array}{c}\text { Normal } \\
27-30\end{array}$ & $\begin{array}{l}\text { Ringan } \\
(21-26)\end{array}$ & $\begin{array}{l}\text { Sedang } \\
(10-20)\end{array}$ & $\begin{array}{c}\text { Lanju } \\
\mathrm{t} \\
(<10) \\
\end{array}$ & \\
\hline SD & $\begin{array}{c}11 \\
(42 \%)\end{array}$ & $\begin{array}{c}8 \\
(30 \%)\end{array}$ & $\begin{array}{c}7 \\
(28 \%)\end{array}$ & 0 & 100 \\
\hline SMP & $\begin{array}{c}5 \\
(38 \%)\end{array}$ & $\begin{array}{c}7 \\
(54 \%)\end{array}$ & $\begin{array}{c}1 \\
(8 \%)\end{array}$ & 0 & 100 \\
\hline SMA & $\begin{array}{c}15 \\
(75 \%)\end{array}$ & $\begin{array}{c}3 \\
(15 \%)\end{array}$ & $\begin{array}{c}2 \\
(10 \%)\end{array}$ & 0 & 100 \\
\hline D3 & $\begin{array}{c}2 \\
(67 \%)\end{array}$ & $\begin{array}{c}1 \\
(33 \%)\end{array}$ & 0 & 0 & \\
\hline S1 & $\begin{array}{c}2 \\
(100 \%)\end{array}$ & 0 & 0 & 0 & \\
\hline $\begin{array}{c}\text { Jumla } \\
\mathrm{h}\end{array}$ & $\begin{array}{c}35 \\
(54,7 \%) \\
\end{array}$ & $\begin{array}{c}19 \\
(29,7 \%) \\
\end{array}$ & $\begin{array}{c}10 \\
(15,6 \%) \\
\end{array}$ & 0 & $\begin{array}{c}64 \\
(100 \%) \\
\end{array}$ \\
\hline
\end{tabular}

Tabel 5 menunjukkan data mengenai wanita postmenopause yang datang di posyandu lansia Rejoagung yang mengalami gangguan kognitif stadium ringan adalah yang berpendidikan terakhir SMP, yaitu dengan persentase 54\% sedangkan kategori gangguan kognitif stadium sedang jumlah persentase yang tertinggi adalah pada wanita dengan pendidikan terakhir SD sebesar $28 \%$, dari hasil penelitian ini dapat disimpulkan bahwa semakin rendah tingkat pendidikan maka akan berpengaruh pada fungsi kognitif, hal ini di mungkinkan karena penggunaan fungsi otak berbeda pada seorang yang berpendidikan dengan tidak bependidikan, Dash dkk (2005) menjelaskan tentang synaptic merupakan persimpangan antara sel-sel otak bagi jalur lalu lintas pulse saraf yang sangat penting untuk mengatur fungsi kognitif dan memori, dimana orang yang berpendidikan tinggi mempunyai lebih banyak synaps di otak dibanding orang yang berpendidikan rendah. Folstein, (1993) menyatakan hasil pemeriksaan MMSE di pengaruhi oleh tingkat pendidikan. Hal ini juga sejalan dengan penelitian yang dilakukan oleh Yuda Turana dan Yvone Suzy Handajani (2011) di Jakarta yang menyimpulkan bahwa nilai MMSE sangat bervariasi pada tingkat pendidika $\neg \mathrm{n}$ rendah sehingga pada penilaian MMSE faktor pendidikan adalah hal yang paling penting dalam menentukan suatu penurunan fungsi kognitif. MMSE merupakan instrumen fungsi kognitif yang men $\neg$ caku $\neg$ p domain kognitif, orientasi, registrasi, atensi, kalkulasi, recal $\neg$ l, dan fungsi bahasa sehingga sangat dipengaruhi oleh tingkat pendidikan seseorang. Dalam pemeriksan MMSE domain kalkulasi, lansia diperintahkan untuk mengurangi angka secara berurutan yang disebutkan oleh pemeriksa sehingga hal ini sangat dipengaruhi oleh faktor pendidikan. Dalam pemeriksaan domain orientasi lansia diperintahkan untuk menjawab pengetahuan umum seperti nama provinsi, kota dan negara sehingga lansia dengan tingkat pengetahuan rendah akan sulit untuk menjawab pertanyaan tersebut sehingga pada hasil pemeriksaan MMSE akan menunjukkan hasil yang rendah pula (Wibisono, 2003). 
Tabel 6. Hasil pemeriksaan MMSE pada wanita postmenopause berdasarkan lama masa postmenopause

\begin{tabular}{|c|c|c|c|c|c|}
\hline \multirow{2}{*}{$\begin{array}{l}\text { Lama } \\
\text { Meno } \\
\text { pause } \\
\text { (tahun } \\
\text { ) }\end{array}$} & \multicolumn{4}{|c|}{ Tingkat gangguan kognitif (MMSE) } & \multirow{2}{*}{$\begin{array}{c}\text { Presenta } \\
\text { se }(\%)\end{array}$} \\
\hline & $\begin{array}{c}\text { Normal } \\
27-30\end{array}$ & $\begin{array}{l}\text { Ringan } \\
(21-26)\end{array}$ & $\begin{array}{l}\text { Sedang } \\
(10-20)\end{array}$ & $\begin{array}{l}\text { Lanjut } \\
(<10)\end{array}$ & \\
\hline $1-5$ & $\begin{array}{c}18 \\
(75 \%)\end{array}$ & $\begin{array}{c}5 \\
(21 \%)\end{array}$ & $\begin{array}{c}1 \\
(4 \%)\end{array}$ & 0 & 100 \\
\hline $6-10$ & $\begin{array}{c}14 \\
(50 \%)\end{array}$ & $\begin{array}{c}9 \\
(32 \%)\end{array}$ & $\begin{array}{c}5 \\
(18 \%)\end{array}$ & 0 & 100 \\
\hline $11-15$ & $\begin{array}{c}2 \\
(22 \%)\end{array}$ & $\begin{array}{c}4 \\
(45 \%)\end{array}$ & $\begin{array}{c}3 \\
(33 \%)\end{array}$ & 0 & 100 \\
\hline$>15$ & $\begin{array}{c}1 \\
(33,4 \%) \\
\end{array}$ & $\begin{array}{c}1 \\
(33,3 \%)\end{array}$ & $\begin{array}{c}1 \\
(33,3 \%) \\
\end{array}$ & 0 & \\
\hline $\begin{array}{c}\text { Jumla } \\
\mathrm{h}\end{array}$ & $\begin{array}{c}35 \\
(54,7 \%) \\
\end{array}$ & $\begin{array}{c}19 \\
(29,7 \%)\end{array}$ & $\begin{array}{c}10 \\
(15,6 \%)\end{array}$ & 0 & $\begin{array}{c}64 \\
(100 \%)\end{array}$ \\
\hline
\end{tabular}

Tabel 6 menunjukkan bahwa wanita dengan lama postmenopause 11-15 tahun adalah yang terbanyak dengan gangguan kognitif stadium ringan (45\%) sedangkan wanita dengan lama masa postmenopause $>15$ tahun adalah yang terbanyak mengalami gangguan kognitif stadium sedang (33,3\%). Hasil penelitian ini sesuai dengan teori Cutter WJ (2003) menyatakan bahwa kadar estrogen yang menurun pada masa postmenopause merupakan salah satu faktor penyebab terjadinya gangguan kognitif pada wanita. Hormon estrogen berfungsi sebagai neuroprotektor, salah satunya dengan cara mencegah terjadinya pembentukan aterosklerosis. Estrogen dapat mempengaruhi metabolisme lipid, dengan menurunkan LDL, dan sebaliknya HDL meningkat yang dapat mencegah terbentuknya aterosklerosis. Pada saat masa postmenopause produksi estrogen akan berkurang, karena hal ini maka fungsi estrogen akan menurun sehingga terjadi pembentukan atoresklerosis yang merupakan salah satu penyebab gangguan vaskuler, yang dapat mengganggu pembuluh darah dan menyebabkan lesi parenkim pada otak yang akhirnya terjadi gangguan kognitif pada wanita postmenopause (Shumaker, 2003). Konsentrasi reseptor estrogen (ERs) pada otak ditemukan tertinggi di hipotalamus dan hipofisis, di ikuti pada hippokampus, mesensefalon dan batang otak, estrogen dideteksi terdapat di sel piramidal CA1 yaitu pada bagian ventral hipokampus, area yang penting untuk fungsi kognitif dan memori (Hale GE, 2005;Cutter WJ, 2003). Peran Estrogen dalam fungsi kognitif antar lain dengan cara meningkatkan sintesa asetilkolin. Asetilkolin merupakan neurotransmitter yang ditemukan di otak bagian cerebral cortex dan hippokampus yang berfungsi mengatur fungsi kognitif, seperti proses penyimpanan dan pemanggilan kembali ingatan, atensi dan respon individu (Gibbs, 1997). Estrogen meningkatkan ekspresi neurotropin yang merupakan senyawa yang berfungsi dalam pemeliharaan dan perkembangan neuron, baik yang terdapat pada organ maupun otak (Osburn, 2002). Estrogen berperan meningkatkan jumlah sinap dengan meningkatkan densitas spine pada dendrit sel piramidal CA1 dan meningkatkan jumlah sinap line, yang berfungsi sebagai penyalur dan penerima informasi dari otak. Estrogen berperan menurunkan akumulasi $\beta$-amiloid dengan meningkatkan bersihan $\beta$-amiloid oleh mikroglia. $\beta$-amiloid merupakan salah satu faktor penyebab penurunan fungsi kognitif yaitu Protein ini melapisi sisi luar sel-sel saraf otak, sehingga membuatnya tidak berfungsi (Osburn, 2001). Estrogen sebagai antiinflamasi, yaitu dengan estradiol menghambat respon inflamasi akibat $\beta$-amiloid yang dapat mengganggu fungsi kognitif (Osburn, 2001). Estrogen meregulasi sitokin, meningkatkan utilisasi glukosa dan juga estrogen berperan meningkatkan produksi protein apolipoprotein yang mempunyai efek protektif terhadap efek toksik aggregasi amiloid, yang dapat menganggu fungsi kognitif (Osburn, 2002).

Kelemahan dari penelitian ini adalah jumlah sampel yang masih kurang, dan juga adanya faktor perancu yang tidak sepenuhnya dapat dikendalikan seperti status perkawinan, pekerjaan, penghasilan, riwayat infeksi otak, riwayat trauma, obat-obatan dan gangguan vaskuler lainnya, yang mana faktor-faktor tersebut dapat mempengaruhi fungsi kognitif dan hasil pemeriksaan MMSE.

\section{KESIMPULAN}

Berdasarkan penelitian yang telah dilakukan didapatkan kesimpulan bahwa, wanita postmenopause di posyandu lansia Rejoagung sebagian besar berusia usia 60-64 tahun dan berpendidikan terakhir SD. Sebagian besar memiliki lama masa postmenopause 6 sampai 10 tahun. Prevalensi gangguan kognitif pada wanita postmenopause di posyandulansia Rejoagung adalah sebesar 45\%.

Berdasarkan hasil pemeriksaan MMSE, gangguan kognitif pada wanita postmenopause terbanyak pada rentang usia 65-69 tahun. Dengan pendidikan terakhir SMP.

Berdasarkan hasil pemeriksaan MMSE, gangguan kognitif terbanyak pada wanita dengan lama masa postmenopause 11-15 tahun,dimana 45\%mengalami gangguankognitif stadium ringan dan pada

wanita denganlama masa postmenopause $>15$ tahun, sekitar 33,3\% mengalami gangguan kognitif stadium sedang.

\section{DAFTAR PUSTAKA}

Baziad, A., 2003, Menopause dan Andropause. Yayasan Bina Pustaka Sarwono Prawirohardjo: Jakarta.

BPPD Kabupaten Tulungagung, 2005, Kependudukan Kabupaten Tulungagung, BPPD Kabupaten Tulungagung, Tulungagung.

Chen SH, Nilson J, Brintor RD, 2006, Dose and temporal pattern of estrogen exposure determinens neuroprotective outcome in hippocampal neurons: therapeutic implications. Endocrinol; 147:5303-13.

Coffey CE, Cummings JL., 2000. Texbook of Geriatric Neuropsychiatry. 2th ed. In: D'Esposito M, editor. Neurobehavioral Syndrome. Washington, DC: American Psychiatric Press; p. 729-745.

Corwin, E.J. 2001. Buku Saku Patofisiologi. Jakarta : EGC Cutter WJ, Norbury R, Murphy DGM, 2003, Oestrogen, brain function, and neuropsychiatric disorders, J NEUROL Neurosurg Psychiatry; 74: 837-40.

Dahlan P, Pemeriksaan neuropsikologi pada demensia. Berkala Neuro Sains;1999;1 Vol 1;43-47.

Depkes, 2005. Terjadi pergeseran umur menopause. Available from http://www.depkes .go.id.

Desmond, D.W., 1996, Vascular dementia: a cons $\neg$ truct in evolution. Cerebrovascular \& Brain Metabolism Reviews, 8 : 296-325. 
Folstein, M F, Rosa, M C, James, C A, \& Basset Sussan, S, 1993, Population Based Norms for the Mini Mental State Examination by Age and Educational Level., JAMA, $269:$ 2386-239.

Friedl, W. Schimdt, R., Stronegger, W.J., Irmler ,A., Reinhart, B., \& Koch, M., 1996. MMSE : Influence of Sociodemoghraphic, Environmental and Behavior Factor and Vascular Risk Factor, J. Clin. Epidemiol. 49 I : 73-78.

Gebbie, A., \& Glasien, A., 2006, Keluarga Berencana \& Kesehatan Reproduksi (Edisi 4). Cetakan Pertama. Jakarta: EGC.

Guyton \& Hall, 1997. Buku ajar fisiologi kedokteran. Edisi 9. Jakarta. EGC.

Good m, Day M, Muir Jl, 1999, Cyclical changes in endogenous level of estrogen modulate the induction of LTD and LTP in the hippocampal CA1 region, J. Neuroscience, 11, 4476-4480.

Gibbs RB, 2000, Long-term Treatment with estrogen and Progesteron enhances AcQuisition of a spatial memory task by overiectomized aged, Neurobiol Aging 21 : 107-116.

Gruber CJ, Tschugguel W, Schneeberger JC, 2002, Production and Actions of Estrogen, NEJM 346 (8):4480.

Hosking D, Chilvers CED, Christiansen C, Ravn P., 1998, Prevention of bone loss with alendronate in postmenopausal Women under 60 years of age. N Engl J Med;338: 485-92

Hurlock, E.B., 1993. Psikologi Perkembangan - Suatu Pendekatan Sepanjang Rentang Kehidupan. Edidi kelima, penerbit Erlangga, Jakarta.

Hardywinoto. 2005.. Panduan Gerontologi: Tinjauan Dari Berbagai Aspek. PT. Cetakan kedua. Gramedia Puataka Utama. Jakarta.

Irawati, Titi, 2002, Usia lanjut (Aging), Menopause. Available from http://www. Kesrepro.info/aging menopause.htm.

Jellinger KA, 2001, Menopause Andropause: Neuroendocrine Changes and Alzheimer's Disease in Postmenopausel Women.

Juby A, Tench S, Baker V, 2002, The Value of clock drawing test in identifying executive cognitive disfungtion in people with a normal Mini-mental State Examination Score, Jurnal Of Cadanian Medica Asociation, pp. 859-864.

Kasdu, D, 2004, Kiat Sehat dan Bahagia di Usia Menopause. Cetakan Pertama. Pustaka Swadaya Nusantara . Jakarta.

Kuntjoro, Z. Sri, 2002.Menopause. available from http:// www.e-psikologi.com/dewasa/index/menopause.htm.

Kuusisto J., Kcijo K., Lcena M., Eeva L., Matti V., \& Tuomo I-L, 1993. Essential Hypertension and Cognitive Function, the Role of Hyper $\neg$ insulinemia, Hypertension, $22: 771-779$.

Kusumoputro, Sidiarto. 2006. Old Age or Disease. Jakarta : Penerbit Universitas Indonesia.

Kesrepro, 2008. Penduduk Indonesia 2025 akan mencapai 273.65 juta jiwa. Available from http:// www.kesrepro.info.

Lezak MD, 1995, Neuropsychological assessment 3rd ed, New York:Oxford University, pp 20-30.
Libby Peter, 2005. The pathogenesis of atherosclerosis. In: Kasper Dennis L, Fauci Anthony S, Longo Dan L, et al. Harrison?s principles of internal medicine. Sixteenth Edition,USA : McGraw-Hill,.h.1425-33.

Liporace j, Pineda CC, Wasserman N, 2002, Neurologic Consideration in the postmenopausal Women in Clinical Neurology of the Older Adult, ed. Sirven J1, Malamut BL, Lipincolt William \& Wilkins.

Lumbantobing SM, 1997. Kecerdasan pada usia lanjut dan demensia. Jakarta; BP FKUI; 1-43.

Luine, VN., Jacome, LF., MacLusky, N.K., 2003, Rapid Enhancement of Visual and Place Memory by Estrogens. Endocrinology, 144, 2836-2844

McEwen BS, 1999, Clinical Review 108 : The Mollecular and Neuroanatomical Basis for Estrogen Effects in The Central Nervous System, J. Clin Endocrinology \& Metab Vol. 6 : 1790-1797.

McEwen BS, 2001, Genome and Hormones : Gender Differences in Physiology invited Review : Estrogen Effects on the Brain : Multiple Sites and Molecular Mechanism, J. Appl Physiol 91 : 2785-2801.

McEwen BS, 2002, Estrogen Actions Throughtout the Brain, The Endocrine Society.

Miller BL,Cummings JL., 1999.The Human Frontal Lobes.In:Kaufer DI,Lewis DA, editors.Frontal lobe anatomy and cortical connectivity.New York:The Guilford Press;.p.27-44

Murphy, D.D \& Segal, M., 1996, Regulation of Dendritic spine densityin ultured rat hippocampal neurons by steroid hormones. J. Neurosci, 16, 4059-4068

Nevid, Feffry. S, 2003. Psikologi Abnormal. Edisi 5 jilid 2. Jakarta: EGC

Netter FH, \& Machado CA., 2003. Atlas of Human Anatomy. Version 3. Icon Learning System LLC.

Osburn, Jennifer, 2002, Estrogen Replacement Therapy in The Treatment of Alzheimer's Disease, int. Journal of Pharmaceutical Compunding, Vol 6 No.3, May/ June.

PERMI, 2007. Profil perempuan menopause di Indonesia dan pengetahuan mengenai terapi insulin hormon. In press 2007.

Purwanto, 2005. Pengantar Perilaku Kesehatan. EGC. Jakarta Potter \& Perry, 1997, Buku Ajar Fundamental Keperawatan: Konsep, proses, dan praktik vol. 1 (edisi 4). Cet. Pertama. Jakarta: EGC.

Purwanto, Setyo, 2007, Menopause. Available fom http:/ / Klinis.Wordpress.com/2007/12/28/menopause.

Purba JS. Demensia dan Penyakit Alzheimer.Jakarta: BP FKUI; $2002: 1-20$

Petersen R C, Doody R, Kurz A., 2001 et al Current concepts in mild cognitive impairment. Arch Neurol. 581985-1992.

Price Sylvia A., \& Lorraine M. Wilson, 2006. Patofisiologi Konsep Klinis Proses-Proses Penyakit (edisi 6), Vol. 2. EGC. Jakarta.hal.1045-1048

Reitz, R., 1993. Menopause Suatu Pendekatan Positif. Bumi Aksara, Jakarta.

Reisberg, B. (2007), and others, The Global Deterioration Scale for Assessment of Primary Degenerative Dementia, Senior Resource Copyright. 
Rochmah W, Harimurti K, 2006, Demensia, In: Aru, Sudoyo, Setiyohadi B, Buku Ajar Ilmu Penyakit Dalam, 4th edn, Pusat Penerbitan Departemen Ilmu Penyakit Dalam Fakultas Kedokteran Universitas Indonesia, Jakarta, pp. 1364-1368.

Shimp, L.A., \& Smith, M.A., 2000. 20 Common Problems in Women's Health Care International Edition 2000. Singapore: McGraw-Hill book Co.

Sutanto, L.B., \& Sutanto, D.B., 2005, Menopause. Jakarta: Balai Penerbit FKUI.

Shumaker SA, Legault C, Rapp SR, Thal L, Wallace RB, Ockene JK, et al, 2003. Estrogen plus progestin and the incidence of dementia and mild cognitive impairment in postmenopausal women. The Women?s Health Initiative Memory Study: A randomized controlled trial. JAMA.;289:2651-62.

Tatemichi, T.K., Paik, M.;Bagiella, P., Desmond, D.W., 1994. Risk of Dementia After Stroke in a Hospitalized Cohort: Results of Longitudinal Study, Neurology. 44: 1885-1881.

Tri Lam T dan Leranth C, 2003, Role of the medial setum diagonal band of Broca cholinergik neurons in oestrogen-induced spine synapse formation on hippocampal CA1 piramidal cell, European Journal Neuroscience, 17: 1997-2005

Turana, Yuda, Yvone SH, 2011, Nilai Mini Mental State Examination (MMSE) Berdasarkan Usia dan Tingkat Pendidikan pada Masyarakat Lanjut Usia di Jakarta, Medika 2011, Tahun ke XXXVII, No. 5, p. 307-310)

Setyopranoto I, Lamsudin R, 1999, Kesepakatan Penilaian Mini Mental State Examination (MMSE) pada Penderita Stroke Iskhemik Akut di RSUP Dr. Sardjito, Yogyakarta, pp 69-73.

Shulman KI, 2000, Clock-drawing: is it the ideal cognitive screening test. Int J Geriatr Psychiatry, pp. 548-561.

Silbernagl S. \& Lang F., 2007. Atlas Berwarna Patofisiologi. Jakarta: EGC

Wahono, Hesthi, 2010, Analisis Faktor-Faktor yang Mempengaruhi Pemamfaatan Posyandu Lansia di Gantungan, Makamhaji, Skripsi thesis, Universitas Muhammadiyah Surakarta.

Wiyoto, 2002, Gangguan Fungsi Kognitif Pada Stroke in Pendidikan Kedokteran Berkelanjutan ilmu penyakit saraf, FK UNAIR, Surabaya, pp 1-31.

Woods NF, Mitchell ES., 2005 Symptoms during the perimenopause: prevalence, severity, trajectory, and significance in women's lives. The American journal of medicine;118:14-24.

Wilson, Sylvia A. Price \& Lorraine M., 2002. Patofisiologi. 6. s.l. : EGC, Vol. II.

Wibisono Sasanto, Prof, dr, DR, SpKJ, K. : "Kuliah Consultation Liaison Psychiatry.” FK UI, 2001. 